https://doi.org/10.22364/hssl.28.2.04

\title{
STRUCTURAL EQUATION MODELING: THE IMPACT OF LEADER ATTITUDES ON THE INNOVATIVE WORK BEHAVIOUR IN REAL ESTATE DEVELOPMENT COMPANIES
}

\section{René Lauck}

M.A. MBA

\begin{abstract}
Leadership and innovation management are academic disciplines of high interest to scholars for decades. The fast changing and volatile business environment require companies to constantly improve their processes to remain competitive on the market. In particular, real estate development companies significantly benefit from innovativeness as each property development is unique, underlies different construction purposes and laws. Therefore, real estate developers need to bring the developable area in line with the building construction. One major driver to boost the competitiveness of organisations can be found in the individual innovative work behaviour of employees. To benefit from the individual's innovative work behaviour, leadership embodies a major influence factor. In particular, this article examines how leader attitudes affect the innovative work behaviour of staff members working in real estate development companies. Therefore, the author developed and calculated a structural equation model to examine this relationship. The results from the structural equation modelling show that integrity and loyalty positively and significantly affect the innovative work behaviour of employees in real estate development companies. Consequently, demonstrating loyalty and integrity from leaders towards staff members improves the innovativeness of the entire organisation. Moreover, this research supports the relevance for the trait approach to leadership as leader attitudes contribute to different extents to the innovative work behaviour.
\end{abstract}

Keywords: innovation management, innovative work behaviour, leader attitudes, leadership, real estate development companies, structural equation modelling

\section{Introduction}

The global competition, maintaining competitiveness, as well as the increasing economic performance requires companies to be innovative. To survive in a vibrant business environment, companies are forced to develop new ideas, products, and strategies in a systematic way. Innovation management has therefore become an indispensable element for gaining 
competitive advantages. ${ }^{1}$ Any company in the era of technological revolution and economic globalisation may not survive on the market without the components of creativity and innovation. ${ }^{2}$ For Amabile (1996), innovation "is the successful implementation of creative ideas within an organization". ${ }^{3}$ De Jong/Den Hartog (2007) consider that organisations can improve their innovativeness by focusing on the employees' individual abilities to be innovative. ${ }^{4}$ To succeed in this vibrant business environment, companies require individuals at every organisational level who are interested in continuous learning and improvements ${ }^{5}$ and leaders represent a major driving force in this management process. ${ }^{6}$ The indispensable necessity of innovation in organisations resulted in focusing on the role of leaders. ${ }^{7}$

Denti/Hemlin (2012) consider leadership as one major driver of innovative organisational performance ${ }^{8}$ as leaders from all organisational levels can contribute to learning and innovation. ${ }^{9}$ The review by Hughes et al. (2018) demonstrates theoretical and empirical support that leadership is a crucial component that affects workplace creativity and innovation. It is recommended conducting further studies to gain a precise understanding which leader behaviours are most important to reveal the mechanisms how to influence their staff members. ${ }^{10}$ Ahmed/Shepherd (2010) further emphasise that the nature of innovations, as well as its impacts are highly

${ }^{1}$ Dereli, D. D. (2015), Innovation Management in Global Competition and Competitive Advantage. Procedia - Social and Behavioral Sciences 195, p. 1366.

${ }^{2}$ Nabil, H., Abderraouf, G., Nadira, R. (2007), The Impact of Leadership on Creativity and Innovation. International Journal of Humanities and Social Science Invention, Vol. 6, Issue 6, p. 55.

${ }^{3}$ Amabile, T. M. (1996), Creativity and Innovation in Organizations. Harvard Business School Background Note 396-239, p. 1.

${ }^{4}$ De Jong, J. P. J., Den Hartog, D. N. (2007), How leaders influence employees' innovative behaviour. European Journal of Innovation Management, Vol. 10, Issue 1, p. 57.

${ }^{5}$ Yukl, G. (2013), Leadership in Organizations. Eighth Edition, Essex, Pearson Education Limited, p. 105.

${ }^{6}$ Carneiro, A. (2008), When leadership means more innovation and development. Business Strategy Series, Vol. 9, Issue 4, p. 176.

${ }^{7}$ Mumford, M. D., Licuanan, B. (2004), Leading for innovation: Conclusions, issues, and directions. The Leadership Quarterly, Vol. 15, Issue 1, p. 163.

${ }^{8}$ Denti, L., Hemlin, S. (2012), Leadership and innovation in organizations: A systematic review of factors that mediate or moderate the relationship. International Journal of Innovation Management, Vol. 16, Issue 3, p. 2.

${ }^{9}$ Yukl, G. (2013), Leadership in Organizations. Eighth Edition, Essex, Pearson Education Limited, p. 109.

${ }^{10}$ Hughes, D. J., Lee, A., Tian, A. W., Newman, A., Legood, A. (2018), Leadership, creativity, and innovation: A critical review and practical recommendations. The Leadership Quarterly, Vol. 29, Issue 5, p. 565. 
complex. ${ }^{11}$ Real estate development companies need to continuously modify their operations to respond timely to changes on the markets. Therefore, the way how real estate development firms respond to changes has significant impacts on the development and survival of the entire organisation. ${ }^{12}$ Real estate development companies create the ideas for property investments and provide the foundation for the construction, commercialization, usage and further investment decisions. ${ }^{13}$

The aim of this article is to examine the relationship between leader attitudes and innovative work behaviour of staff members in real estate development companies by developing and calculating a structural equation modelling. In the following, the theoretical background of the trait theory, as well as the relevance and dimensions of innovative work behaviour are outlined.

\section{Theoretical background and analysis of the trait approach to leadership}

One of the first systematic attempts to research leadership can be found in the trait approach ${ }^{14}$ which dominated the beginning of leadership studies. ${ }^{15}$ The trait approach to leadership follows the assumption that leaders possess traits which distinguishes them from non-leaders. ${ }^{16}$ Trait theories do not distinguish between traits inherited or acquired and were also labelled as Great Man theories. ${ }^{17}$ Robertson/Callinan (1998) already pointed out that personality affects several work-related factors. ${ }^{18}$

${ }^{11}$ Ahmed, P. K., Shepherd, C. D. (2010), Innovation Management. Context, strategies, systems and processes. Essex, Pearson Education Limited, p. 4.

${ }^{12}$ Steele, J., Murray, M. (2004), Creating, supporting and sustaining a culture of innovation. Engineering, Construction and Architectural Management, Vol. 11, Issue 5, p. 317.

${ }^{13}$ Brauer, K. U. (2011), Einfuihrung in die Immobilienwirtschaft. In: Brauer, K. U. (Ed.), Grundlagen der Immobilienwirtschaft. Recht - Steuern - Marketing - Finanzierung Bestandsmanagement - Projektentwicklung. 7., überarbeitete Auflage, Wiesbaden, Gabler Verlag, p. 33.

${ }^{14}$ Yukl, G. (2013), Leadership in Organizations. Eighth Edition, Essex, Pearson Education Limited, p. 142.

${ }^{15}$ Zaccaro, S. J. (2007), Trait-Based Perspectives of Leadership. American Psychologist. Vol. 62, Issue 1, p. 6.

${ }^{16}$ Colbert, A. E., Judge, T. A., Choi, D., Wang, G. (2012), Assessing the trait theory of leadership using self and observer ratings of personality: The mediating role of contributions to group success. The Leadership Quarterly, Vol. 23, Issue 4, p. 670.

${ }^{17}$ Kirkpatrick, S. A., Locke, E. A. (1991), Leadership: do traits matter? Academy of Management Executive, Vol. 5, Issue 2, p. 48.

${ }^{18}$ Robertson, I., Callinan, M. (1998), Personality and Work Behaviour. European Journal of Work and Organizational Psychology, Vol. 7, Issue 3, p. 336. 
According to Zaccaro/Kemp/Bader (2004), the term "trait" underlies confusion in the academic literature, referring variously to personality, temperaments, dispositions, abilities, as well as to qualities of leaders. ${ }^{19}$ Based on that, different types of research have been conducted to examine the trait approach. ${ }^{20}$ Stogdill's (1948) first survey was conducted to identify traits and characteristics of leaders. The results from the research show five factors to be associated with leadership: capacity, achievement, responsibility, participation and status. For Stogdill (1948), these results are not surprising as leaders hold a position which implies interaction and the fulfilment of the given tasks. Consequently, a further factor needs to be considered namely the situation. This means that leaders might perform well in a specific situation and fail in others. ${ }^{21}$ Mann (1959) performed a study to research the relationship between personality and the performance in groups. The results show that intelligence, adjustment, extroversion, dominance, masculinity, and conservatism are traits that could be used to distinguish leaders from other individuals. ${ }^{22} 23$ In contrast, Lord/De Vader/Alliger (1986) only found three personality traits namely intelligence, masculinity - femininity, and dominance associated with leaders and argue that personality traits are related with leadership to a higher degree than expected and indicated by the literature. ${ }^{24} \mathrm{~A}$ more recent analysis by Kirkpatrick/Locke (1991) explicitly emphasises that leaders are not like others and can be distinguished from non-leaders in several aspects which are drive, leadership motivation, honesty and integrity, self-confidence, cognitive ability, knowledge of the business and other traits that are of weaker support such as charisma, creativity/ originality, and flexibility. Kirkpatrick/Locke (1991) further outline that leaders do not have to be great by having outstanding intellectual abilities, but they need to have certain qualities which are not equally distributed

${ }^{19}$ Zaccaro, S. J., Kemp, C., Bader, P. (2004), Leader traits and attributes. In: Antonakis, J., Cianciolo A. T., Sternberg R. J. (Ed.), The nature of leadership, Thousand Oaks, Sage Publications, p. 103.

${ }^{20}$ Yukl, G. (2013), Leadership in Organizations. Eighth Edition, Essex, Pearson Education Limited, p. 143.

${ }^{21}$ Stogdill, R. M. (1948), Personal Factors Associated with Leadership: A Survey of the Literature. The Journal of Psychology, Vol. 25, Issue 1, pp. 35, 64-65.

${ }^{22}$ Mann, R. D. (1959), A review of the relationships between personality and performance in small groups. Psychological Bulletin, Vol. 56, Issue 4, pp. 264-265.

${ }^{23}$ Northouse, P. G. (2016), Leadership. Theory and Practice. Seventh Edition, Thousand Oaks, Sage Publications, p. 21.

${ }^{24}$ Lord, R. G., De Vader, C. L., Alliger, G. M. (1986), A Meta-Analysis of the Relation Between Personality Traits and Leadership Perceptions: An Application of Validity Generalization Procedures. Journal of Applied Psychology, Vol. 71, Issue 3, p. 407. 
in people. For example, business or technical knowledge originates from training and job experience whereas honesty is a virtue by choice. ${ }^{25}$

The trait approach fits with the notion that leaders are unique individuals that significantly contribute to the welfare in our society. Moreover, the trait approach benefits from a century of research activities to back it up and no other leadership theory has been researched in such a depth and breadth which simultaneously gives this theory a measure of creditability that other leadership approaches lack. ${ }^{26}$

Yukl (2013) outlines that significant progress has been achieved in research in order to detect traits of effective leaders. ${ }^{27}$ Northouse (2016) highlights that the trait approach fails to examine cause-effect relationships. Previous research mainly focused on identifying traits but did not thoroughly research how leadership traits affect staff members' ${ }^{6}$ work. ${ }^{28}$

\section{The relevance and dimensions of innovative work behaviour}

According to Potočnik/Anderson (2016), the research fields of creativity and innovation, as well as behavioural science are aimed at explaining how individuals, teams, and companies deal with organisational changes to foster the organisational functioning. By considering the relevance of effective change and innovation management to remain competitive on the market and to ensure the long-term survival of the organisation, research in these fields has flourished in the past years. ${ }^{29}$ In particular, research into innovation in general reveals wide disparity between different definitions but shows some similarities such as novelty, application, intentionality of benefit, and a procedural component. ${ }^{30}$

${ }^{25}$ Kirkpatrick, S. A., Locke, E. A. (1991), Leadership: do traits matter? Academy of Management Executive, Vol. 5, Issue 2, pp. 48-49, 58.

${ }^{26}$ Northouse, P. G. (2016), Leadership. Theory and Practice. Seventh Edition, Thousand Oaks, Sage Publications, p. 30.

${ }^{27}$ Yukl, G. (2013), Leadership in Organizations. Eighth Edition, Essex, Pearson Education Limited, p. 163.

${ }^{28}$ Northouse, P. G. (2016), Leadership. Theory and Practice. Seventh Edition, Thousand Oaks, Sage Publications, p. 31.

${ }^{29}$ Potočnik, K., Anderson, N. (2016), A constructively critical review of change and innovation-related concepts: towards conceptual and operational clarity. European Journal of Work and Organizational Psychology, Vol. 25, Issue 4, p. 481.

${ }^{30}$ West, M. A., Altink, W. M. M. (1996), Innovation at work: Individual, group, organizational, and socio-historical perspectives. European Journal of Work and Organizational Psychology, Vol. 5, Issue 1, pp. 4-5. 
One method to improve the organisational innovativeness is by focusing on the staff members' individual ability to innovate, ${ }^{31}$ but research on innovative work behaviour (IWB) remains relatively underdeveloped. ${ }^{32}$ For Singh/Sarkar (2012), innovative behaviour of employees represents a vital resource for organisational sustainability and development. ${ }^{33}$ In particular, de Jong/den Hartog (2010) stress that researchers and practitioners consider innovative work behaviour as crucial for the organisational success, but the precise measurement of the latent variable (construct) is still at an early stage. ${ }^{34}$ Janssen (2000) defines innovative work behaviour „as the intentional creation, introduction and application of new ideas within a work role, group or organization, in order to benefit role performance, the group, or the organization." Based on that definition, innovative work behaviour examines the intentional efforts of staff members to generate novelties in a business environment. Consequently, innovative work behaviour can contribute to a better functioning of the company. ${ }^{35}$ De Jong/den Hartog (2010) outline that innovative work behaviour can be divided into different dimensions which are connected along the innovative process. In this respect, De Jong/den Hartog (2010) distinguish between four dimensions of innovative work behaviour and define them as idea exploration, idea generation, idea championing, and idea implementation. ${ }^{36}$ The following figure illustrates the construct of innovative work behaviour.

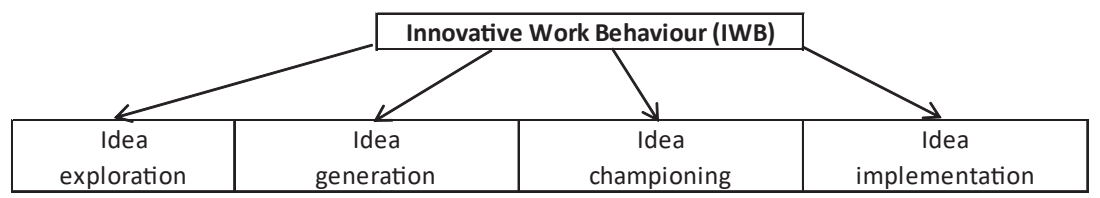

Source: De Jong/Den Hartog, 2010, p. 30

Figure 1. Construct of Innovative Work Behaviour (IWB)

${ }^{31}$ De Jong, J. P. J., Den Hartog, D. N. (2007), How leaders influence employees' innovative behaviour. European Journal of Innovation Management, Vol. 10, Issue 1, p. 41.

32 Wolfe, R. A. (1994), Organizational Innovation: Review, Critique and Suggested Research Directions. Journal of Management Studies, Vol. 31, Issue 3, p. 405.

33 Singh, M., Sarkar, A. (2012), The Relationship Between Psychological Empowerment and Innovative Behavior. A Dimensional Analysis with Job Involvement as Mediator. Journal of Personnel Psychology, Vol. 11, Issue 3, p. 127.

${ }^{34}$ De Jong, J. P. J., Den Hartog, D. N. (2010), Measuring Innovative Work Behaviour. Creativity and Innovation Management, Vol. 19, Issue 1, p. 23.

35 Janssen, O. (2000), Job demands, perceptions of effort-reward fairness and innovative work behaviour. Journal of Occupational and Organizational Psychology, Vol. 73, Issue 3, p. 288.

${ }^{36}$ De Jong, J. P. J., Den Hartog, D. N. (2010), Measuring Innovative Work Behaviour. Creativity and Innovation Management, Vol. 19, Issue 1, p. 24. 
According to Scott/Bruce (1994), the process-related point of view of individual innovation starts by recognising a problem followed by the development of possible solutions. The solutions can be either novel or adapted by the staff member. In the next phase, the employee is searching for other individuals who support the idea and tries to establish a coalition of proponents. The final step in the innovation process entails the implementation of the idea in practice. ${ }^{37}$

The concept of innovative work behaviour can be fostered through active learning and practicing. ${ }^{38}$ Besides, a study performed by Prieto/ Pérez-Santana (2014) shows that high-involvement in human resource practices in the ability-enhancing and opportunity-enhancing domains are connected with innovative work behaviour and boost working conditions in which support from the management and from colleagues affects the development and appreciation of staff members' ideas. Abilityenhancing human resource practices deal with both choosing employees, as well as training whereas opportunity-enhancing human resource practices focus on improving the job design and involvement practices. ${ }^{39}$ By considering age and tenure of staff members, research conducted by $\mathrm{Ng} /$ Feldman (2013) did not found a relationship between these observed variables and innovation-related behaviour. The research results are still important because it shows that older and more experienced staff members are not less innovative. Following that, older and longer-tenured employees are as innovative as their younger colleagues. ${ }^{40}$ Sameer (2018) found that innovative behaviour positively correlates with satisfaction and engagement and recommends placing more emphasis on the staff members' creativity and innovative behaviour to boost the organisational success. ${ }^{41}$ The meta-analysis from Hammond et al. (2011) found that

${ }^{37}$ Scott, S. G., Bruce, R. A. (1994), Determinants of Innovative Behavior: A Path Model of Individual Innovation in the Workplace. The Academy of Management Journal, Vol. 37, Issue 3, pp. 581-582.

${ }^{38} \mathrm{Niu}, \mathrm{H}-\mathrm{J}$. (2014), Is innovation behaviour congenital? Enhancing job satisfaction as a moderator. Personnel Review, Vol. 43, Issue 2, p. 291.

${ }^{39}$ Prieto, I. M., Pérez-Santana, M. P. (2014), Managing innovative work behavior: the role of human resource practices. Personnel Review, Vol. 43, Issue 2, p. 200.

${ }^{40} \mathrm{Ng}$, T. W. H., Feldman, D. C. (2013), A meta-analysis of the relationships of age and tenure with innovation-related behaviour. Journal of Occupational and Organizational Psychology, Vol. 86, Issue 4, p. 602.

${ }^{41}$ Sameer, Y. M. (2018), Innovative behavior and psychological capital: Does positivity make any difference? Journal of Economics and Management, Vol. 32, Issue 2, pp. 90, 94. 
individual factors, job characteristics as well as contextual variables are central factors in better understanding creativity and innovation at work. ${ }^{42}$

Similarly, a research study conducted by Bysted (2013) indicates that job satisfaction and mental involvement show a positive moderating effect on innovative work behaviour. Moreover, it could be examined that job satisfaction positively affects the relationship between innovation trust and innovative work behaviour. Consequently, staff members who are satisfied with their jobs demonstrate a broader range of novel ideas. In addition, mental involvement moderates job autonomy on innovative work behaviour and fosters the overall innovative job performance. Following that, staff members who are mentally involved show a higher effectiveness in using their time to produce innovative results. Bysted (2013) derives that managers on all levels need to raise awareness for innovation and develop conditions in which staff members are not afraid of developing new ideas. ${ }^{43}$ Moreover, Tierney/Farmer/Graen (1999) found that staff members who enjoy creativity-related tasks show a higher level of innovative output. Furthermore, employees who work together with their supervisors and have a similar intrinsic motivational direction, increase their creative outputs as well. ${ }^{44}$ Miron/Erez/Naveh (2004) found in their empirical study that innovation performance is determined by three components that include creativity and initiative, creativity and innovative culture, and initiative and innovative culture. Thus, creativity alone is not a sufficient factor for innovative performance. ${ }^{45}$ Ramamoorthy et al. (2005) found that job design and autonomy of employees have strong impact on innovative work behaviour. ${ }^{46}$

From the organisational point of view, Gundry et al. (2016) researched that employees who feel committed to the company produce higher innovation outcomes. In particular, organisational commitment caused

${ }^{42}$ Hammond, M. M., Neff, N. L., Farr, J. L., Schwall, A. R., Zhao, X. (2011), Predictors of Individual-Level Innovation at Work: A Meta-Analysis. Psychology of Aesthetics, Creativity, and the Arts, Vol. 5, Issue 1, p. 102.

${ }^{43}$ Bysted, R. (2013), Innovative employee behaviour - The moderating effects of mental involvement and job satisfaction on contextual variables. European Journal of Innovation Management, Vol. 16, Issue 3, pp. 280-281.

${ }^{4}$ Tierney, P., Farmer, S. M., Graen, G. B. (1999), An Examination of Leadership and Employee Creativity: The Relevance of Traits and Relationships. Personnel Psychology, Vol. 52, Issue 3, p. 612.

${ }^{45}$ Miron, E., Erez, M., Naveh, E. (2004), Do personal characteristics and cultural values that promote innovation, quality, and efficiency compete or complement each other? Journal of Organizational Behavior, Vol. 25, Issue 2, p. 192.

${ }^{46}$ Ramamoorthy, N., Flood, P. C., Slattery, T., Sardessai, R. (2005), Determinants of Innovative Work Behaviour: Development and Test of an Integrated Model. Creativity and Innovation Management, Vol. 14, Issue 2, p. 148. 
administrative and technical innovations. ${ }^{47}$ For Galbraith (1982), organisations need to be designed in such a way that structures, processes, rewards, and employees are combined in order to develop innovations. Consequently, organisations need to fulfil two tasks, the operating and innovating function. The ideas developed in the innovating organisations need to be implemented and transferred in the operating organisation to generate innovation. ${ }^{48}$

Yuan/Woodman (2010) conducted a study to research how the expected outcomes of employees influence work innovations. The results indicate that expectations for potential performance and image consequences have a significant impact on the staff members' innovative work behaviour. Following that, employees demonstrate a higher level of innovativeness if they anticipate and perceive that this behaviour is beneficial for their work. In contrast, potential image risks and unfavourable social impressions negatively affected the innovative behaviour at work. ${ }^{49}$ Moreover, research by Basu/Green (1997) demonstrates that the exchange quality between leaders and followers positively affect the innovative behaviour. ${ }^{50}$ In this respect, De Spiegelaere et al. (2014) could research in their study that job insecurity has a negative impact on the innovative work behaviour of staff members. In contrast, staff members who receive a high level of autonomy show a positive relation with innovative work behaviour. Following that, job insecurity is a fundamental factor that limits the possibility to demonstrate innovative work behaviour. ${ }^{51}$

Janssen (2005) conducted an empirical study to examine how the relationship between leaders and followers affects the innovative work behaviour. Results indicate that staff members are more likely to demonstrate innovative work behaviour when leaders show appreciation and support for innovation. In particular, the findings suggest that employees consider

${ }^{47}$ Gundry, L. K., Muñoz-Fernandez, A., Ofstein, L. F., Ortega-Egea, T. (2016), Innovating in Organizations: A Model of Climate Components Facilitating the Creation of New Value. Innovating in Organizations, Vol. 25, Issue 2, p. 232.

${ }^{48}$ Galbraith, J. R. (1982), Designing the Innovating Organization. Organizational Dynamics, Vol. 10, Issue 3, pp. 5-6.

${ }^{49}$ Yuan, F., Woodman, R. W. (2010), Innovative behavior in the workplace: The role of performance and image outcome expectations. Academy of Management Journal, Vol. 53, Issue 2, pp. 334-335.

${ }^{50}$ Basu, R., Green, S. G. (1997), Leader-Member Exchange and Transformational Leadership: An Empirical Examination of Innovative Behaviors in Leader-MemberDyads. Journal of Applied Social Psychology, Vol. 27, Issue 6, p. 489.

${ }^{51}$ De Spiegelaere, S., Van Gyes, G., De Witte, H., Niesen, W., Van Hootegem, G. (2014), On the Relation of Job Insecurity, Job Autonomy, Innovative Work Behaviour and the Mediating Effect of Work Engagement. Creativity and Innovation Management, Vol. 23, Issue 3, p. 326. 
their superiors as key actors who have the power to support or reject further innovative developments. The perception of staff members of how leaders respond to novel ideas and how they use their power to influence the project has significant impacts on the demonstration of the staff members' innovative work behaviour. ${ }^{52}$

Montani/Battistelli/Odoardi (2015) researched motivational dynamics that underlie individual innovativeness. In particular, research shows how proactive goal generation affects the innovative work behaviour. The findings support the hypothesis that proactive goal generation is a strong predictor of innovative work behaviour. ${ }^{53}$ For Basadur (2004), the most effective leaders aim at supporting staff members, as well as teams and include their differing styles through a process of creativity that entails the discovery and definition of working related issues, solving emerging problems, and implementing these solutions in work practice. Dealing with creative solutions enables leaders to foster the organisational performance significantly. ${ }^{54}$ Research conducted by Elkins/Keller (2003) shows that leading groups does not solely mean focusing on staff members. It is recommended spanning boundaries with constituents outside the projects such as with other managers, marketing professionals and customers. $^{55}$ By examining different leadership styles affecting the innovativeness of staff members, Lee (2008) found that transformational leadership has a positive and significant impact on the innovativeness of employees whereas transactional leadership shows an inverse relation with innovativeness. ${ }^{56}$ Similarly, Gumusluoğlu/llsev (2009) could provide support for the hypothesis that transformational leadership has positive impacts on the overall organisational innovation for micro-and small-sized companies.

52 Janssen, O. (2005), The joint impact of perceived influence and supervisor supportiveness on employee innovative behaviour. Journal of Occupational and Organizational Psychology, Vol. 78, Issue 4, p. 578.

${ }^{53}$ Montani, F., Battistelli, A., Odoardi, C (2015), Proactive Goal Generation and Innovative Work Behavior: The Moderating Role of Affective Commitment, Production Ownership and Leader Support for Innovation. Journal of Creative Behavior, Vol. 51, Issue 2, p. 120.

${ }^{54}$ Basadur, M. (2004), Leading others to think innovatively together: Creative leadership. The Leadership Quarterly, Vol. 15, Issue 1, p. 103.

${ }^{55}$ Elkins, T., Keller, R. T. (2003), Leadership in research and development organizations: A literature review and conceptual framework. The Leadership Quarterly, Vol. 14, Issues 4-5, p. 601.

${ }^{56}$ Lee, J. (2008), Effects of leadership and leader-member exchange on innovativeness. Journal of Managerial Psychology, Vol. 23, Issue 6, p. 678. 
Moreover, external support for innovation moderated the relationship between transformational leadership style and organisational innovation. ${ }^{57}$

\section{Development and calculation of the structural equation modelling of the relationship between leader attitudes and innovative work behaviour of employees in real estate development companies}

Structural equation modelling (SEM) is a statistical method that is frequently applied in business and social science research to model latent variables (constructs), to consider different types of measurement errors and to examine theories. ${ }^{58}$ In particular, SEM can be described as multivariate technique with the ability to analyse linear and/or causal relationships between exogenous and endogenous latent variables underlying simultaneous, multiple equation estimation procedures. Consequently, the execution of SEM may contribute to moving theories to new and higher levels of understanding of human behaviours. ${ }^{59}$ For the underlying research, the author uses the partial least squares structural equation modelling (PLS-SEM) that represents a more regression based procedure to reduce the residual variances of the exogenous latent variables. Comparing the partial least squares structural equation modelling with the covariance based structural equation modelling, the PLS-SEM is considered to be more robust, operates well with small and large sample sizes and is able to include reflective and formative indicators for measuring the constructs. ${ }^{60}$

Northouse (2016) already pointed out that the trait approach fails to delimit a concrete list of leader attitudes. Although leadership studies have been conducted over decades, the list of traits seems to be endless. ${ }^{61}$ Therefore, the author performed a content analysis to identify attitudes of leaders that are considered to be vital in leadership. The results show that

${ }^{57}$ Gumusluoğlu, L., Ilsev, A. (2009), Transformational Leadership and Organizational Innovation: The Roles of Internal and External Support for Innovation. Journal of Product Innovation Management, Vol. 26, Issue 3, p. 273.

${ }^{58}$ Henseler, J., Hubona, G., Ray, P. A. (2016), Using PLS path modeling in new technology research: updated guidelines. Industrial Management \& Data Systems, Vol. 116, Issue 1, p. 2.

${ }^{59}$ Babin, B. J., Svensson, G. (2012), Structural equation modeling in social science research. Issues of validity and reliability in the research process. European Business Review, Vol. 24, Issue 4, p. 321.

${ }^{60}$ Hair, J. F., Ringle, C. M., Sarstedt, M. (2011), PLS-SEM: Indeed a Silver Bullet. Journal of Marketing Theory and Practice, Vol. 19, Issue 2, p. 143.

${ }^{61}$ Northouse, P. G. (2016), Leadership. Theory and Practice. Seventh Edition, Thousand Oaks, Sage Publications, pp. 30-31. 
trust, motivation, loyalty, respect, communication, openness, and empathy are leader attitudes that are most discussed in the literature. ${ }^{62}$ Consequently, the author defines the identified leader attitudes as independent latent variables for this research. Again, the aim of this research is to examine how attitudes of leaders towards their staff members affect the innovative work behaviour in real estate development companies.

The following figure shows the research model with eight independent latent variables (leader attitudes) and one dependent latent variable (innovative work behaviour).

leader attitudes

innovative work behaviour

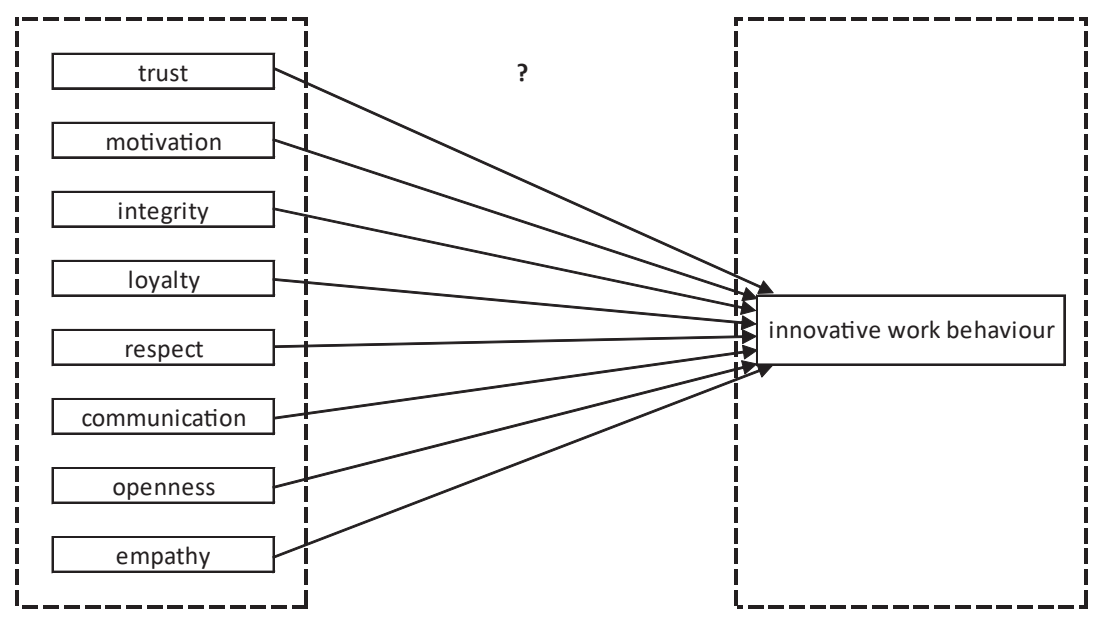

Source: author's compilation

Figure 2. Research Model

In total, 137 employees from eight different countries working in real estate development companies fully answered the questionnaire. The survey was available both online as well as paper-based. The analysis of the participants shows that $56 \%$ are male and $44 \%$ are female. Moreover, $37 \%$ of the employees were between 26 years and 35 years followed by $29 \%$ of employees who show an age span between 36 years and 45 years. In addition, most participants had a work experience between four and six years.

${ }^{62}$ Lauck, R. (2019), Content Analysis: Identification of Leader Personality Traits Affecting the Innovative Work Behaviour. Proceedings of IAC in Vienna 2019, p. 191. 


\section{Measures and assessment of PLS-SEM}

To measure the latent variables in this research model, the author used and modified indicators from previous studies. In this respect, a 5-point Likert scale ranging from (1) strongly disagree to (5) strongly agree was applied.

Research shows that 5-point Likert scales reduce the frustration level of the participants and increase the response rates and quality of answering the questions. ${ }^{63}$ In this respect, Likert (1932) points out that both extremes of attitudes are covered consistently with this scale. ${ }^{64}$

The leader attitude "trust" was measured by using ten modified items from McAllister (1995). ${ }^{65}$ The participants were asked to evaluate the relationship with their immediate leader. Cronbach's Alpha amounted to $\alpha=.91$ for this scale.

Integrity was measured with five indicators from Adams/Sartori $(2006)^{66}$ with a Cronbach's Alpha of $\alpha=.91$. Next, openness of leaders towards staff members was measured with eight items from Wood/ Winston $(2007)^{67}$ showing an internal consistency of $\alpha=.86$. Besides, the leader attitude "respect" was measured with five items developed by van Quaquebeke/Brodbeck (2008) ${ }^{68}$ with a Cronbach's Alpha of $\alpha=.77$. Communication between leaders and employees was determined by four modified items from Chen/Paulraj (2004) ${ }^{69}$ showing a Cronbach's Alpha of $\alpha=.86$. The leader attitude "loyalty" was measured by a modified scale including three items from Liden/Maslyn (1998) ${ }^{70}$ with a Cronbach's

${ }^{63}$ Sachdev, S. B., Verma, H. V. (2004), Relative Importance of Service Quality Dimensions: A Multisectoral Study. Journal of Services Research, Vol. 4, Issue 1, p. 104.

${ }^{64}$ Likert, R. (1932), A Technique for The Measurement of Attitudes. Archives of Psychology, Vol. 22, p. 46.

${ }^{65}$ McAllister, D. J. (1995), Affect- and Cognition-Based Trust as Foundations for Interpersonal Cooperation in Organizations. The Academy of Management Journal, Vol. 38, Issue 1, p. 37.

${ }^{66}$ Adams, B. D., Sartori, J. A. (2006), Validating the trust in teams and trust in leaders. Humansystems Incorporated, p. 41.

${ }^{67}$ Wood, J. A., Winston, B. E. (2007), Development of three scales to measure leader accountability. Leadership \& Organization Development Journal, Vol. 28, Issue 2, p. 178.

${ }^{68}$ Van Quaquebeke, N., Brodbeck, F. C. (2008), Entwicklung und erste Validierung zweier Instrumente zur Erfassung von Führungskräfte-Kategorisierung im deutschsprachigen Raum. Zeitschrift für Arbeits- u. Organisationspsychologie, Vol. 52, p. 80.

${ }^{69}$ Chen, I. J., Paulraj, A. (2004), Towards a theory of supply chain management: the constructs and measurements. Journal of Operations Management, Vol. 22, Issue 2, p. 141.

${ }^{70}$ Liden, R. C., Maslyn, J. M. (1998), Multidimensionality of Leader-Member Exchange: An Empirical Assessment through Scale Development. Journal of Management, Vol. 24, Issue 1, p. 56. 
Alpha of $\alpha=.84$. Next, motivation was evaluated with three indicators adapted from Gagné et al. $(2010)^{71}$ showing a Cronbach's Alpha of $\alpha=.91$. The last leader attitude "empathy" was measured with six modified items from Kellett/Humphrey/Sleeth (2002) $)^{72}$ and shows a Cronbach's Alpha of $\alpha=.88$. The depended latent variable "innovative work behaviour" was captured with eight adapted items from de Jong/den Hartog (2010) ${ }^{73}$ showing a Cronbach's Alpha of $\alpha=.85$. Moreover, the research results do not show issues with the composite reliability as all computed values exceed the minimum cut-off value of $.60 .{ }^{74}$

In addition, convergent validity was assessed by computing the average variance extracted (AVE). The calculated values range from .50 until .85 . The latent variables explain at least more than half of the variance of its items. $^{75}$

Next, as traditional approaches such as the Fornell-Larcker criterion performed poorly and did not reliability detect discriminant validity issues in simulation studies performed by Henseler/Ringle/Sarstedt (2015), the heterotrait-monotrait ratio of correlations (HTMT) was computed. ${ }^{76}$ The results show no issues with the discriminant validity as the computed values for all constructs do not exceed the cut-off value of $.90 .{ }^{77}$

To analyse collinearity issues, the variance inflation factor (VIF) was computed. ${ }^{78}$ The results indicate no issues with collinearity as the values

${ }^{71}$ Gagné, M., Forest, J., Gilbert, M. H., Aubé, C., Morin, E., Malorni, A. (2010), The Motivation at Work Scale: Validation Evidence in Two Languages. Educational and Psychological Measurement, Vol. 70, Issue 4, p. 641.

${ }^{72}$ Kellett, J. B., Humphrey, R. H., Sleeth, R. G. (2002), Empathy and complex task performance: two routes to leadership. The Leadership Quarterly, Vol. 13, Issue 5, p. 540.

${ }^{73}$ De Jong, J., Den Hartog, D. (2010), Measuring Innovative Work Behaviour. Creativity and Innovation Management, Vol. 19, Issue 1, p. 29.

${ }^{74}$ Hair, J. F., Hult, G. T. M., Ringle, C. M., Sarstedt, M., Richter, N. F., Hauff, S. (2017), Partial Least Squares Strukturgleichungsmodellierung (PLS-SEM). Eine anwendungsorientierte Einführung. Vahlen Verlag, München, p. 97.

${ }^{75}$ Hair, J. F., Hult, G. T. M., Ringle, C. M., Sarstedt, M. (2014), A Primer on Partial Least Squares Structural Equation Modeling (PLS-SEM). Sage Publications, Thousand Oaks, p. 103.

${ }^{76}$ Henseler, J., Ringle, C. M., Sarstedt, M. (2015), A new criterion for assessing discriminant validity in variance-based structural equation modeling. Journal of the Academy of Marketing Science, Vol. 43, p. 124.

77 Ibid., p. 129.

${ }^{78}$ Hair, J. F., Hult, G. T. M., Ringle, C. M., Sarstedt, M. (2014), A Primer on Partial Least Squares Structural Equation Modeling (PLS-SEM). Sage Publications, Thousand Oaks, p. 124. 
do not exceed the threshold of ten. ${ }^{79}$ A further criterion can be found in the coefficient of determination $\left(R^{2}\right)$ to evaluate the explained variance of the exogenous latent variable in structural model. The underlying research model shows an $R^{2}$ of .35 and is considered to be medium for the target construct. ${ }^{80}$

\section{Results}

The bootstrapping procedure calculates amongst other values the path coefficients and p-values for the latent variables. ${ }^{81}$ In this respect, the author defines $5 \%(\alpha=0.05)$ as critical value for the significance level. The following figure three illustrates the standardised path coefficients and p-values of the relationship between the independent variables (leader attitudes) and depended variable (innovative work behaviour) of staff members working in real estate development companies computed with SmartPLS.

In particular, the results show that the leader attitudes integrity (p-value $=0.002)$ and loyalty ( $\mathrm{p}$-value $=0.001)$ have a significant impact on the innovative work behaviour of employees in real estate development companies. By comparing both leader attitudes integrity and loyalty, the standardised path coefficient for loyalty $(0.44)$ demonstrates a stronger relationship with innovative work behaviour compared to integrity $(0.36)$.

${ }^{79}$ Marquardt, D. W. (1970), Generalized Inverses, Ridge Regression, Biased Linear Estimation, and Nonlinear Estimation. Technometrics, Vol. 12, Issue 3, p. 610.

${ }^{80}$ Hair, J. F., Hult, G. T. M., Ringle, C. M., Sarstedt, M. (2014), A Primer on Partial Least Squares Structural Equation Modeling (PLS-SEM). Sage Publications, Thousand Oaks, p. 198.

${ }^{81}$ Willaby, H. W., Costa, D. S. J., Burns, B. D., MacCann, C., Roberts, R. D. (2015), Testing complex models with small sample sizes: A historical overview and empirical demonstration of what Partial Least Squares (PLS) can offer differential psychology. Personality and Individual Differences, Vol. 84, p. 74. 
leader attitudes

innovative work behaviour

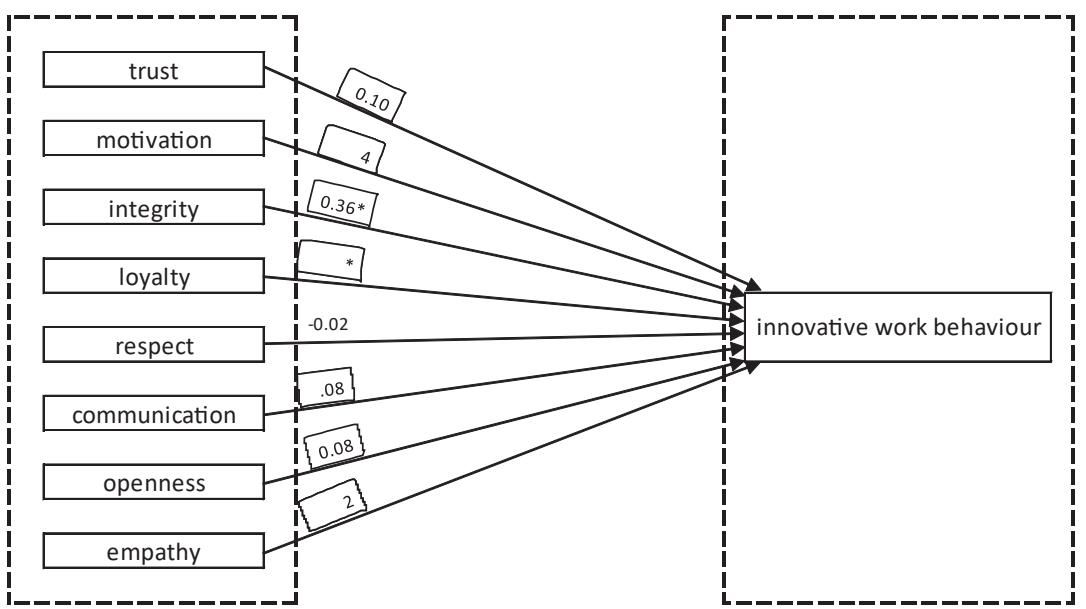

(exogene variables)

(endogene variable)

*p-value: $<0.00$

Source: author's compilation

Figure 3. Research Model with Results

Consequently, the research results show that certain leader attitudes have a higher impact on innovative work behaviour than others. Based on these findings it can be highlighted that the trait approach to leadership is still relevant for management science. Although the author did not distinguish between different situations, the research results show a consistent picture. Moreover, it confirms the assumption of the author that real estate development companies are organisations (open systems) that require constant improvements ranging from the idea development until the construction of the property.

\section{Conclusions, recommendations to leaders and scientists and further research}

The underlying study is a first systematic attempt to examine the relationship between leader attitudes and innovative work behaviour of staff members working in real estate development companies. Based on the literature review and empirical research results from the structural equation modelling, the following conclusions can be drawn including recommendations to leaders and scientists. Moreover, the author offers 
suggestions for further research to broaden the understanding of the complex research areas leadership and innovation management:

1. Innovation management and leadership are topics of high interest to scholars for decades. This research shows that leader attitudes are a mechanism to foster the innovative work behaviour of employees in real estate organisations to remain competitive on the market.

2. In particular, research results indicate that integrity and loyalty have a significant impact on the innovative work behaviour of employees in real estate development companies. Consequently, leaders who show integrity and loyalty towards their staff members boost the overall success and innovativeness of the entire organisation.

3. In addition, innovative work behaviour is a multidimensional latent variable that follows certain sequences of steps ranging from the idea development until the implementation. Real estate development companies are open systems that benefit from innovative work behaviour as each project and construction is individual which requires a constant improvement of the processes along the entire value chain.

4. Therefore, leaders need to create an environment in which staff members have the opportunity to generate novel ideas. It becomes obvious that generating innovative work behaviour requires additional time and embodies an extra role.

5. It is recommended that leaders determine their current leadership attitudes and put emphasize on leading with loyalty and integrity to boost the organisational innovativeness and success. In addition, workshops and trainings can help leaders to improve their leadership skills.

6. Granting financial and non-financial incentives to employees who successfully showed innovative work behaviour with appropriate results is recommended.

7. From the organisational perspective, companies need to consider the topic of innovation in their organisational structure explicitly. A company culture, a frequent exchange between different departments, and sufficient time are needed to develop novel ideas.

8. Furthermore, future research is essential to examine how culture affects the relevance of leader attitudes in affecting the staff members' innovative work behaviour.

9. Moreover, the trait approach to leadership suffers under inconsistent measurements of the latent variables (leader attitudes) as researchers started to combine or mixing up traits. Therefore, researchers are advised to thoroughly distinguish between leader attitudes to make results comparable. 
10. Finally, additional research is essential if groups of staff members require different leader attitudes than single staff members to be more innovative at work.

\section{REFERENCES}

1. Adams, B. D., Sartori, J. A. (2006), Validating the trust in teams and trust in leaders. Humansystems Incorporated, pp. 1-80.

2. Amabile, T. M. (1996), Creativity and Innovation in Organizations. Harvard Business School Background Note 396-239, pp. 1-15.

3. Ahmed, P. K., Shepherd, C. D. (2010), Innovation Management. Context, strategies, systems and processes. Essex, Pearson Education Limited.

4. Babin, B. J., Svensson, G. (2012), Structural equation modeling in social science research. Issues of validity and reliability in the research process. European Business Review, Vol. 24, Issue 4, pp. 320-330.

5. Basadur, M. (2004), Leading others to think innovatively together: Creative leadership. The Leadership Quarterly, Vol. 15, Issue 1, pp. 103-121.

6. Basu, R., Green, S. G. (1997), Leader-Member Exchange and Transformational Leadership: An Empirical Examination of Innovative Behaviors in Leader-MemberDyads. Journal of Applied Social Psychology, Vol. 27, Issue 6, pp. 477-499.

7. Brauer, K. U. (2011), Einführung in die Immobilienwirtschaft. In: Brauer, K. U. (Ed.), Grundlagen der Immobilienwirtschaft. Recht - Steuern - Marketing - Finanzierung Bestandsmanagement - Projektentwicklung. 7., überarbeitete Auflage, Wiesbaden, Gabler Verlag, pp. 1-56.

8. Bysted, R. (2013), Innovative employee behaviour - The moderating effects of mental involvement and job satisfaction on contextual variables. European Journal of Innovation Management, Vol. 16, Issue 3, pp. 268-284.

9. Carneiro, A. (2008), When leadership means more innovation and development. Business Strategy Series, Vol. 9, Issue 4, pp. 176-184.

10. Chen, I. J., Paulraj, A. (2004), Towards a theory of supply chain management: the constructs and measurements. Journal of Operations Management, Vol. 22, Issue 2, pp. 119-150.

11. Colbert, A. E., Judge, T. A., Choi, D., Wang, G. (2012), Assessing the trait theory of leadership using self and observer ratings of personality: The mediating role of contributions to group success. The Leadership Quarterly, Vol. 23, Issue 4, pp. 670-685.

12. De Jong, J. P. J., Den Hartog, D. N. (2007), How leaders influence employees' innovative behaviour. European Journal of Innovation Management, Vol. 10, Issue 1, pp. 41-64.

13. De Jong, J. P. J., Den Hartog, D. N. (2010), Measuring Innovative Work Behaviour. Creativity and Innovation Management, Vol. 19, Issue 1, pp. 23-36.

14. De Spiegelaere, S., Van Gyes, G., De Witte, H., Niesen, W., Van Hootegem, G. (2014), On the Relation of Job Insecurity, Job Autonomy, Innovative Work Behaviour and 
the Mediating Effect of Work Engagement. Creativity and Innovation Management, Vol. 23, Issue 3, pp. 318-330.

15. Denti, L., Hemlin, S. (2012), Leadership and innovation in organizations: A systematic review of factors that mediate or moderate the relationship. International Journal of Innovation Management, Vol. 16, Issue 3, pp. 1-20.

16. Dereli, D. D. (2015), Innovation Management in Global Competition and Competitive Advantage. Procedia - Social and Behavioral Sciences 195, pp. 1365-1370.

17. Elkins, T., Keller, R. T. (2003), Leadership in research and development organizations: A literature review and conceptual framework. The Leadership Quarterly, Vol. 14, Issues 4-5, pp. 587-606.

18. Gagné, M., Forest, J., Gilbert, M. H., Aubé, C., Morin, E., Malorni, A. (2010), The Motivation at Work Scale: Validation Evidence in Two Languages. Educational and Psychological Measurement, Vol. 70, Issue 4, pp. 628-646.

19. Galbraith, J. R. (1982), Designing the Innovating Organization. Organizational Dynamics, Vol. 10, Issue 3, pp. 5-25.

20. Gumusluoğlu, L., Ilsev, A. (2009), Transformational Leadership and Organizational Innovation: The Roles of Internal and External Support for Innovation. Journal of Product Innovation Management, Vol. 26, Issue 3, pp. 264-277.

21. Gundry, L. K., Muñoz-Fernandez, A., Ofstein, L. F., Ortega-Egea, T. (2016), Innovating in Organizations: A Model of Climate Components Facilitating the Creation of New Value. Innovating in Organizations, Vol. 25, Issue 2, pp. 223-238.

22. Hair, J. F., Hult, G. T. M., Ringle, C. M., Sarstedt, M. (2014), A Primer on Partial Least Squares Structural Equation Modeling (PLS-SEM). Sage Publications, Thousand Oaks.

23. Hair, J. F., Hult, G. T. M., Ringle, C. M., Sarstedt, M., Richter, N. F., Hauff, S. (2017), Partial Least Squares Strukturgleichungsmodellierung (PLS-SEM). Eine anwendungsorientierte Einführung. Vahlen Verlag, München.

24. Hair, J. F., Ringle, C. M., Sarstedt, M. (2011), PLS-SEM: Indeed a Silver Bullet. Journal of Marketing Theory and Practice, Vol. 19, Issue 2, pp. 139-151.

25. Hammond, M. M., Neff, N. L., Farr, J. L., Schwall, A. R., Zhao, X. (2011), Predictors of Individual-Level Innovation at Work: A Meta-Analysis. Psychology of Aesthetics, Creativity, and the Arts, Vol. 5, Issue 1, pp. 90-105.

26. Henseler, J., Hubona, G., Ray, P. A. (2016), Using PLS path modeling in new technology research: updated guidelines. Industrial Management \& Data Systems, Vol. 116, Issue 1, pp. 2-20.

27. Henseler, J., Ringle, C. M., Sarstedt, M. (2015), A new criterion for assessing discriminant validity in variance-based structural equation modeling. Journal of the Academy of Marketing Science, Vol. 43, pp. 115-135.

28. Hughes, D. J., Lee, A., Tian, A. W., Newman, A., Legood, A. (2018), Leadership, creativity, and innovation: A critical review and practical recommendations. The Leadership Quarterly, Vol. 29, Issue 5, pp. 549-569.

29. Janssen, O. (2000), Job demands, perceptions of effort-reward fairness and innovative work behaviour. Journal of Occupational and Organizational Psychology, Vol. 73, Issue 3, pp. 287-302. 
30. Janssen, O. (2005), The joint impact of perceived influence and supervisor supportiveness on employee innovative behaviour. Journal of Occupational and Organizational Psychology, Vol. 78, Issue 4, pp. 573-579.

31. Kellett, J. B., Humphrey, R. H., Sleeth, R. G. (2002), Empathy and complex task performance: two routes to leadership. The Leadership Quarterly, Vol. 13, Issue 5, pp. 523-544.

32. Kirkpatrick, S. A., Locke, E. A. (1991), Leadership: do traits matter? Academy of Management Executive, Vol. 5, Issue 2, pp. 48-60.

33. Lauck, R. (2019), Content Analysis: Identification of Leader Personality Traits Affecting the Innovative Work Behaviour. Proceedings of IAC in Vienna 2019, pp. 188-193.

34. Lee, J. (2008), Effects of leadership and leader-member exchange on innovativeness. Journal of Managerial Psychology, Vol. 23, Issue 6, pp. 670-687.

35. Liden, R. C., Maslyn, J. M. (1998), Multidimensionality of Leader-Member Exchange: An Empirical Assessment through Scale Development. Journal of Management, Vol. 24, Issue 1, pp. 43-72.

36. Likert, R. (1932), A Technique for The Measurement of Attitudes. Archives of Psychology, Vol. 22, pp. 5-55.

37. Lord, R. G., De Vader, C. L., Alliger, G. M. (1986), A Meta-Analysis of the Relation Between Personality Traits and Leadership Perceptions: An Application of Validity Generalization Procedures. Journal of Applied Psychology, Vol. 71, Issue 3, pp. 402-410.

38. Mann, R. D. (1959), A review of the relationships between personality and performance in small groups. Psychological Bulletin, Vol. 56, Issue 4, pp. 241-270.

39. Marquardt, D. W. (1970), Generalized Inverses, Ridge Regression, Biased Linear Estimation, and Nonlinear Estimation. Technometrics, Vol. 12, Issue 3, pp. 591-612.

40. McAllister, D. J. (1995), Affect- and Cognition-Based Trust as Foundations for Interpersonal Cooperation in Organizations. The Academy of Management Journal, Vol. 38, Issue 1, pp. 24-59.

41. Miron, E., Erez, M., Naveh, E. (2004), Do personal characteristics and cultural values that promote innovation, quality, and efficiency compete or complement each other? Journal of Organizational Behavior, Vol. 25, Issue 2, pp. 175-199.

42. Montani, F., Battistelli, A., Odoardi, C. (2015), Proactive Goal Generation and Innovative Work Behavior: The Moderating Role of Affective Commitment, Production Ownership and Leader Support for Innovation. Journal of Creative Behavior, Vol. 51, Issue 2, pp. 107-127.

43. Mumford, M. D., Licuanan, B. (2004), Leading for innovation: Conclusions, issues, and directions. The Leadership Quarterly, Vol. 15, Issue 1, pp. 163-171.

44. Nabil, H., Abderraouf, G., Nadira, R. (2007), The Impact of Leadership on Creativity and Innovation. International Journal of Humanities and Social Science Invention, Vol. 6, Issue 6, pp. 55-62.

45. Ng, T. W. H., Feldman, D. C. (2013), A meta-analysis of the relationships of age and tenure with innovation-related behaviour. Journal of Occupational and Organizational Psychology, Vol. 86, Issue 4, pp. 585-616. 
46. Niu, H-J. (2014), Is innovation behaviour congenital? Enhancing job satisfaction as a moderator. Personnel Review, Vol. 43, Issue 2, pp. 288-302.

47. Northouse, P. G. (2016), Leadership. Theory and Practice. Seventh Edition, Thousand Oaks, Sage Publications.

48. Potočnik, K., Anderson, N. (2016), A constructively critical review of change and innovation-related concepts: towards conceptual and operational clarity. European Journal of Work and Organizational Psychology, Vol. 25, Issue 4, pp. 481-494.

49. Prieto, I. M., Pérez-Santana, M. P. (2014), Managing innovative work behavior: the role of human resource practices. Personnel Review, Vol. 43, Issue 2, pp. 184-208.

50. Ramamoorthy, N., Flood, P. C., Slattery, T., Sardessai, R. (2005), Determinants of Innovative Work Behaviour: Development and Test of an Integrated Model. Creativity and Innovation Management, Vol. 14, Issue 2, pp. 142-150.

51. Robertson, I., Callinan, M. (1998), Personality and Work Behaviour. European Journal of Work and Organizational Psychology, Vol. 7, Issue 3, pp. 321-340.

52. Sachdev, S. B., Verma, H. V. (2004), Relative Importance of Service Quality Dimensions: A Multisectoral Study. Journal of Services Research, Vol. 4, Issue 1, pp. 93-116.

53. Sameer, Y. M. (2018), Innovative behavior and psychological capital: Does positivity make any difference? Journal of Economics and Management, Vol. 32, Issue 2, pp. 75-101.

54. Scott, S. G., Bruce, R. A. (1994), Determinants of Innovative Behavior: A Path Model of Individual Innovation in the Workplace. The Academy of Management Journal, Vol. 37, Issue 3, pp. 580-607.

55. Singh, M., Sarkar, A. (2012), The Relationship Between Psychological Empowerment and Innovative Behavior. A Dimensional Analysis with Job Involvement as Mediator. Journal of Personnel Psychology, Vol. 11, Issue 3, pp. 127-137.

56. Steele, J., Murray, M. (2004), Creating, supporting and sustaining a culture of innovation. Engineering, Construction and Architectural Management, Vol. 11, Issue 5, pp. 316-322.

57. Stogdill, R. M. (1948), Personal Factors Associated with Leadership: A Survey of the Literature. The Journal of Psychology, Vol. 25, Issue 1, pp. 35-71.

58. Tierney, P., Farmer, S. M., Graen, G. B. (1999), An Examination of Leadership and Employee Creativity: The Relevance of Traits and Relationships. Personnel Psychology, Vol. 52, Issue 3, pp. 591-620.

59. Van Quaquebeke, N., Brodbeck, F. C. (2008), Entwicklung und erste Validierung zweier Instrumente zur Erfassung von Führungskräfte-Kategorisierung im deutschsprachigen Raum. Zeitschrift für Arbeits- $u$. Organisationspsychologie, Vol. 52, pp. 70-80.

60. West, M. A., Altink, W. M. M. (1996), Innovation at work: Individual, group, organizational, and socio-historical perspectives. European Journal of Work and Organizational Psychology, Vol. 5, Issue 1, pp. 3-11.

61. Willaby, H. W., Costa, D. S. J., Burns, B. D., MacCann, C., Roberts, R. D. (2015), Testing complex models with small sample sizes: A historical overview and empirical demonstration of what Partial Least Squares (PLS) can offer differential psychology. Personality and Individual Differences, Vol. 84, pp. 73-78. 
62. Wolfe, R. A. (1994), Organizational Innovation: Review, Critique and Suggested Research Directions. Journal of Management Studies, Vol. 31, Issue 3, pp. 405-431.

63. Wood, J. A., Winston, B. E. (2007), Development of three scales to measure leader accountability. Leadership \& Organization Development Journal, Vol. 28, Issue 2, pp. 167-185.

64. Yuan, F., Woodman, R. W. (2010), Innovative behavior in the workplace: The role of performance and image outcome expectations. Academy of Management Journal, Vol. 53, Issue 2, pp. 323-342.

65. Yukl, G. (2013), Leadership in Organizations. Eighth Edition, Essex, Pearson Education Limited.

66. Zaccaro, S. J. (2007), Trait-Based Perspectives of Leadership. American Psychologist. Vol. 62, Issue 1, pp. 6-16.

67. Zaccaro, S. J., Kemp, C., Bader, P. (2004), Leader traits and attributes. In: Antonakis, J., Cianciolo A. T., Sternberg R. J. (Ed.), The nature of leadership, Thousand Oaks, Sage Publications, pp. 101-124. 